\title{
The Political Economy of Industrial Policy: Structural Interdependencies, Policy Alignment and Conflict Management
}

\author{
Antonio Andreoni* and Ha-Joon Chang** \\ *Department of Economics, SOAS University of London and South African Research Chair \\ in Industrial Development, University of Johannesburg \\ *Faculty of Economics and Centre of Development Studies, University of Cambridge
}

\begin{abstract}
Industrial policy is back in the mainstream debates. The paper provides a long-term analytical perspective of the industrial policy debate, and it critically assesses the current mainstream phase of the debate in light of three fundamental theoretical insights that developed along several decades of industrial policy theory and practice. These are related to the (i) structural interdependencies, tensions and dualism arising in the industrialisation process; (ii) variety and types of institutions for industrialisation and the importance of policy alignment; (iii) conflict management role of the government, alongside his entrepreneurial function, and the importance of government organisational capabilities. Building on this theoretical analysis, the last section of the paper provides a framework for the strategic coordination of packages of interactive industrial policy measures. The Policy Package Matrix is introduced as an operationalisation of the framework and a tool for effective industrial policy making.
\end{abstract}

\section{Keywords:}

Industrial policy

Structural interdependencies

Institutions for industrialisation

Policy alignment

Conflict management

Strategic coordination and Policy Package Matrix 
"There still are, nevertheless, respectable patrons of opinions, unfriendly to the encouragement of manufactures" (Alexander Hamilton, 1791:1)

\section{Introduction}

Industrial policy has been the subject of one of the most heated debates in economics from its earliest days, even though the term, industrial policy, was not used widely until the postWWII period. During the second half of the $20^{\text {th }}$ century, for a couple of decades industrial policy was widely debated and deployed in both developing and industrialised countries. Developing countries saw industrial policy as the key for post-colonial independence and social development. The latter group of countries, especially across Europe, engaged in economic planning and industrial policy to reconstruct the productive and social foundations of their economies.

Starting from the 1970s, with the rise of neoliberalism, industrial policy were discredited in the academic and policy debates, although traditional industrial policy tools were not completely abandoned. Industrial policy went undercover in many leading industrial nations, while late industrialisers across East Asia made industrial policy the main tool for their catching up in the globalising economy.

Despite the fact that the East Asian miracle represented a historical disproof of the neoliberal anti-industrial policy narrative already in the 1990s, industrial policy managed to resurface in the mainstream debates only recently. Since the mid-2000s, and increasingly after the global financial crisis, several academics have proclaimed industrial policy alive again, and policy makers across countries have tried to adapt industrial policy instruments and institutions to the new global industrial landscape.

While this is a positive turn in the industrial policy debate, the recent mainstreaming of industrial policy presents a number of analytical limitations and policy risks. In particular, the risk of capturing and diluting industrial policy and, as a result, making it ineffective in practice. The paper aims at providing a long-term analytical perspective of the industrial policy debate, and critically assess the current mainstream phases of the debate in light of the fundamental theoretical insights that developed along several decades of industrial policy theory and practice. Specifically, the paper focuses on three key set of issues which we argue have been lost in the current industrial policy debate. These are (i) a structuralist understanding of interdependencies, tensions and dualism arising in the industrialisation process; (ii) an understanding of the variety and types of institutions for industrialisation and the importance of policy alignment; (iii) the conflicts management function of the government, alongside his entrepreneurial function, and the importance of government organisational capabilities.

Building on this theoretical analysis, the last section of the paper provides a framework for the strategic coordination of packages of interactive industrial policy measures. This framework points to the fact that industrial policy effectiveness as well as policy selectivity will be critically dependent on the extent to which governments are able to strategically coordinate different sets of instruments acting upon different policy domains and targeting different levels of the economy. Strategic coordination of industrial policy is 
understood as an institutionally structured process, that is, a process which can be structured using different policy and organisational models.

By focusing on the industrial policy process and on strategic coordination issues, institutional and policy complementarities can be better exploited, policies can be better aligned in time and over time, and the different capabilities, incentives and interests of the players operating within the government and across the private sector can be organised to overcome conflicts and achieve higher levels of industrial competitiveness. The Policy Package Matrix is finally introduced as an operationalisation of the framework and a tool for effective industrial policy making.

\section{Deconstructing the debate: The 'history of economic analysis' of industrial policy}

Since the eighteenth century, even before the appearance of Adam Smith's celebrated Wealth of Nations (1976[1776]), Antonio Serra's Short Treatise (1613) addressed the problems of underdevelopment by focusing on economies of scale and agglomeration, with a specific focus on manufacturing, as well as the relationship between balance of trade and balance of payments. Paolo Mattia Doria and David Hume investigated what they called the 'jealousy of trade' (Hont, 2005), while Antonio Genovesi in Naples and Cesare Beccaria in Milan proposed a set of policies that nations should follow in order to develop their manufactures and escape a situation of dependency. Since these seminal contributions, there have been four main phases in the history of the debate on industrial policy.

In a Schumpeterian fashion, the following sections provide a 'history of economic analysis' of industrial policy, pointing to four main distinctive phases and more importantly the increasing mainstreaming of industrial policy over the last decade.

\subsection{The first phase: The infant industry}

The first phase of the debate on industrial policy started with the dawn of capitalism, building on early contributions by economists like Antonio Serra, Giovanni Botero, and James Stewart arguing for deliberate government promotion of the manufacturing sector (Reinert, 1995). In particular, this gathered pace with Alexander Hamilton, the first ever Treasury Secretary of the USA. Even before David Ricardo developed the theory of comparative advantage, Hamilton had developed the infant industry argument, against the then dominant doctrine of free trade (Hamilton, 1791 is the seminal text). As is well known, the theory is based on a rather simple but powerful insight that a catch-up country needs to protect its young industries against the competition from superior foreign producers, in the same way in which we protect our children before we send them into the adult world (see Chang, 2007a, ch. 3, for an exposition of this doctrine along this line; also see Cohen and DeLong, 2016).

Most people think that Hamilton used his theory only to justify tariff protection. However, he also recommended a host of other industrial policy measures, such as subsidies for strategic industries, tariff rebates on imported inputs used for exports, export ban on key raw materials, and the imposition of product standards by the government. Significantly, these are measures associated with the East Asian 'miracle' economies but, even more significantly, were also those that had already been used by Britain, especially under Robert Walpole (Prime Minister, 1721-42) (Brisco, 1907; Chang, 2002). Hamilton also recommended a host of policies that are not industrial policy in the usual sense but support industrialisation, such as those regarding infrastructure (e.g., government investments in canals and roads) and finance (e.g., the developments of the banking sector and of the government bond market). 
Hamilton's theory was developed by Friedrich List (List, 1885 [1841]) and have influenced generations of industrial policy-makers in a wide range of countries, from $19^{\text {th }}$ century US and Sweden to the 'miracle' economies of late $20^{\text {th }}$-century East Asia. Naturally, along the way, there were heated debates, with big names like Gustav Schmoller, John Stuart Mill, Frank Taussig, and Bertil Ohlin throwing in their weights.

The first phase of the industrial policy debate focused on whether it makes sense to forego income in the short run by protecting inefficient producers that may or may not bring a higher income tin the long run. Unfortunately, there were few discussions of 'systemic' issues: the balance between different sectors of the economy (especially between agriculture and manufacturing); the balance between different sectors within manufacturing (especially between the capital goods sectors and the consumer goods sector). Also, there were virtually no discussions of the relative merits of different tools of industrial policy (e.g., tariffs, subsidies, regulation) nor those issues related to policy implementation (e.g., administrative structure, bureaucratic capabilities, institutional mechanisms, or corruption).

\subsection{The second phase: Inter-sectoral and structural issues}

The second phase started in the early to mid-20 $20^{\text {th }}$ century with the debate on Soviet industrialisation (see Erlich, 1960, and Ellman, 1979) and was further developed between the 1940s and the 1960s by 'classic' Development Economists, interested in the issue of developing post-colonial economies of Latin America, India, and Eastern Europe: the important names included Celso Furtado, Arthur Lewis, Raul Prebisch, Han Singer, Paul Rosentein-Rodan, Prasanta Chandra Mahalanobis, Ragnar Nurkse, Tibor Scitovsky, Albert Hirschman, Simon Kuznets, Michal Kalecki, and Alexander Gerschenkron (key readings from many of these economists can be found in Agarwala \& Singh (eds.), 1958).

The second phase of industrial policy debate was often conducted at the 'systemic' and 'structural' levels, especially around its positions on the generation and the transfer of surplus from the agrarian sector to the industrial sector. However, it also brought to our attention a number of issues that are relevant for more narrowly defined 'industrial policy'.

First, the dynamic nature of the manufacturing sector was very much emphasised. Although this issue had been at the foundation of the infant industry argument, the second wave provided a more systematic explanation for the phenomenon, by deploying concepts like income elasticity, scale economies, and monopolistic competition.

Second, reflecting the influence of the Classical and the Marxist schools, the different roles that the capital goods and the consumer goods sectors play within manufacturing were highlighted, sometimes with the latter further divided into the wage goods and the luxury goods sectors. These distinctions have shown that different industries have different implications on capital accumulation, inflation, economic growth, income distribution, and living standards.

Third, and relatedly, the second phase theories very much highlighted the reliance of backward economies on imported capital goods and the consequent constraints that foreign exchange shortage impose on the paces of physical investment, technological change, and economic growth. Some, especially Raul Prebisch, emphasised the importance of export (and the policies to promote it) in overcoming these constraints.

Last but not least, the second phase theories very much emphasised the interdependence between different branches of manufacturing industry both in terms of technologies and of demands (especially the 'big push' argument and Hirschman's linkage argument). They argued that policy-makers can deliberately exploit these interdependences and accelerate industrialisation. 
The second phase ideas were subject to strong Neoclassical criticisms since the 1970s. Two issues stand out.

First, Neoclassical economists accused the second phase theorists of issuing misleading recommendations because of their excessive pessimism about international trade - especially the emphases on import substitution, the development of the capital goods industry, and the co-development of sectors producing final goods and those that supply capital goods and intermediate inputs to them (the 'big push' or 'balanced growth'). All of these problems would disappear, the Neoclassical critics argued, if the backward economies can earn enough foreign exchanges through exports. Their ability to export, in turn, would be maximised if those countries followed their comparative advantage, which will require the state not having any industrial policy - or at most the 'general' ones of providing infrastructure, education, and R\&D. Unfortunately, the advocates of industrial policy in the second phase did not counter the Neoclassical argument by pointing out that sticking to comparative advantage may lead to a lower capacity to export in the long run than under an infant industry programme combined with export promotion policy (Lin \& Chang, 2009; Chang, 2011a) ${ }^{1}$.

Second, the second phase theorists were accused by the Neoclassical economists of being naïve about the intention and the capabilities of the state in backward economies. The politicians and the bureaucrats who run industrial policy in those countries do not necessarily (or, rather, usually don't) intend to promote national interests but use industrial policy to promote interests of their own (e.g., bureaucrats wield more power when there are more regulations over private sector activities) or their supporters (e.g., politicians will bow to pressures from industrialists or trade unions and protect inefficient industries). The risk of 'government failure', it was said, was more serious than those of market failures. Although the advocates of industrial policy in the second phase were actually aware of the problem of government failure (Toye, 1987), it is also true that they did not fully acknowledge the importance of the issue (Chang, 1994).

\subsection{The third phase: The full works}

Partly overlapping with the second phase, the third phase of debate on industrial policy was started in the late 1970s. A heated debate erupted in the US between those who argued that the US should use Japanese style industrial policy in order to halt its industrial decline (Magaziner \& Hout, 1980; Johnson, 1982; Reich, 1982; Cohen \& Zysman, 1987; Okimoto, 1989; Dertouzos et al., 1989) and those who argued that such policy was not a reason for Japan's industrial ascendancy (Trezise, 1983) or that it couldn't be applied to the US (Badaracco \& Yoffie, 1983).

In the 1980s, industrial policies of other advanced economies were also discussed. The French industrial policy, which had until then been discussed as an element of French 'indicative planning' (Cohen, 1977), also attracted attention, partly because of its similarity with the Japanese one (Hayward, 1986; Hall, 1987). Industrial policies of small European economies were discussed, especially their negotiated (rather than directed) nature, in contrast to the East Asian or the French ones (Katzenstein, 1985). Less visible industrial policy by local governments in Germany and Italy were also brought to attention (Piore \& Sabel, 1984; Best, 1990). By the late 1980s, industrial policy practices in (and their impacts on the economic successes of) the less developed East Asian economies, namely, South

\footnotetext{
${ }^{1}$ See also Prebisch 1950 and Pasinetti (1981:259) who pointed out how "the primary source of international gains is international learning (not international trade)".
} 
Korea and Taiwan, were also brought under scrutiny (Amsden, 1989, and Chang, 1994 on Korea; Amsden, 1985, and Wade, 1990, on Taiwan).

One noticeable thing about the third phase of the debate was that many participants in the debate were denying the very existence of the thing they were supposed to be debating on. For example, as late as in 1988, the free-trade economist Bela Balassa argued that the role of the state in Korea "apart from the promotion of shipbuilding and steel . . . has been to create a modern infrastructure, to provide a stable incentive system, and to ensure that government bureaucracy will help rather than hinder exports" (Balassa 1988: 286). A leading academic saying such a thing, at a time when a quick reading of the financial press or a brief conversation with a foreign businessman with experiences in Korea or Taiwan would have revealed the prevalence and the strength of industrial policy in those economies, shows how ideological the debate was in the third wave.

Subsequently, when it became difficult to deny the existence of industrial policy in these countries, the criticisms focused on the effectiveness of industrial policy in the East Asian countries themselves (the best example is World Bank, 1993; see Rodrik, 1994, Lall, 1994, and Chang, 1995 for criticisms) or the feasibility of drawing lessons from those countries for other countries, given the 'special' nature of history, politics, and institutions in those countries (see Chang, 1994a and 2011a, for criticisms of this kind of argument).

The third phase has naturally covered the issues raised in the earlier waves: the logic of infant industry vs. the theory of comparative advantage; export promotion vs. import substitution; state failure vs. market failure. However, it also brought out some new issues.

First, it drew our attention to issues of competition and cooperation among domestic firms. In the previous phases, the issue of competition was discussed mainly in relation to the exposure of the firms in a backward economy to superior foreign competitors. In the third phase, well-calibrated regulation of competition between domestic firms regarding investment, export, and other activities, was also highlighted. It was argued that such regulations bring social benefits by ensuring that firms have more than minimum efficient scale, by reducing duplication of efforts, and by reducing the chance of 'excessive competition' leading to the scrapping (rather then re-deployment) of 'specific assets' owned by failed companies (Johnson, 1982; Chang, 1994; Amsden \& Singh, 1994)

Second, the third wave highlighted the importance of implementation issues. In addition to the leadership's political will and the capabilities of the bureaucrats executing policies, attention was drawn to the institutions that are used for its implementation: the way the government is organized (e.g., how much coordination is there between different ministries); how the private sector is organized (e.g., whether they have well-functioning associations at the national, regional, and sectoral levels); and how the state and the private sector interact (e.g., whether there is a mechanism for regular exchange of opinions between key policy-makers and business leaders; whether there are effective 'intermediate institutions' in the public sector that provide critical inputs, like R\&D, to the private sector) (Dore, 1986; Chang, 1994 and 2011a; Evans, 1995; see Andreoni, 2016 and Andreoni et al., 2017 for an elaboration of the concept of intermediate institutions).

Third, the process of learning by producers was more explicitly theorized in the third phase, especially among evolutionary economists focusing on firm- and system- level innovation dynamics. Of course, learning is at the heart of the infant industry argument, but the standard infant industry argument assumes that learning automatically happens, once an appropriate level of protection is provided. In the third phase, it was recognized that, while some learning happens automatically through 'learning by doing', much of it requires deliberate investments in the capabilities to learn (education, training, and R\&D). This microorganisational perspective was also promoted by scholars focusing on micro-structural 
production dynamics, technological change, industrial districts and context specific industrial dynamics (Becattini, 1989; Best, 1990; Lazonick, 1990; Andreoni, 2014 and 2018).

The National Systems of Innovation literature pioneered by Christopher Freeman, Bengt-Åke Lundvall and Richard Nelson pointed out the need to have explicit innovation policy on a number of grounds: infrastructural and institutional problems; technological lockin, path dependency, and transition failures; quality of linkages and networks configuration failures; finally, issues related to learning dynamics at the firm, local networks, sectoral and system levels (Metcalfe, 1995; Malerba, 2002; Andreoni, 2018). These contributions share a holistic conception of the innovation process and, more distinctively, a multi-layered representation of industrial systems, whereby agents (i.e. firms, research centres, intermediaries etc.) are embedded in a network of horizontal and vertical interdependences that determine their production and innovation performances. They highlighted that systemic failures may unfold both within and across regional and national industrial systems, all of them being interconnected through global supply chains.

\subsection{The fourth phase: 'Mainstreaming' of industrial policy and its limitations}

From the mid- 2000s, we have entered the fourth phase of debate on industrial policy. During this period, we have seen the emergence of some important arguments justifying industrial policy on the basis of Neoclassical economics.

First, there is the 'information externality' argument of Ricardo Hausmann and Dani Rodrik (Hausmann \& Rodrik, 2002; Rodrik, 2004; Hausmann \& Rodrik, 2006). In this argument, in addition to the failures of the market to coordinate investments between related industries (the 'big push') and to supply 'public goods' (such as rules, standards, or R\&D), information externality is seen as a major obstacle to industrial diversification in developing countries. Hausmann and Rodrik point out that a firm that enters a new industry before the others generates new information about the feasibility of the industry for other potential entrants but is not compensated for the risk it has to take to be the 'pioneer'. The result is that there will be less than optimal entry into new industries, hampering industrial diversification and thus economic development. Given this, the government is justified in compensating the 'pioneer' (or 'innovator') firms by giving them targeted subsidies in the form of loans and loan guarantees ${ }^{2}$ Hausamann \& Rodrik (2002) explicitly advise against trade protection or export subsidies on the ground that they do not discriminate between the innovator and the imitators. $^{3}$

Second, Justin Lin has developed what he calls New Structural Economics and, as a tool to apply it to industrial policy-making, the so-called Growth Identification and Facilitation (GIF) approach (Lin, 2012). While still sticking to the Neoclassical notion of factor-endowment-based comparative advantage, the GIF recommends that developing countries should not simply stick to their current patterns of comparative advantage but should try to anticipate their future ones and develop industries that fit them. Lin recommends that developing country governments should try to promote the production of "tradable goods and services that have been produced for about 20 years in dynamically

\footnotetext{
${ }^{2}$ Hausmann and Rodrik also advocate industrial policy to provide the 'public goods', like R\&D, needed for the relevant industries

${ }^{3}$ However, it is argued that, even though they do not discriminate in favour of the pioneers, export subsidies are still better than import protection, because they benefit only the better firms, which are able to enter the international markets.
} 
growing countries with similar endowment structures and a per capita income that is about 100\% higher than their own" (Lin, 2012:161).

Unfortunately, these supposedly original arguments are rather clumsy translations of old ideas by non-Neoclassical schools into the Neoclassical language. The Hausmann-Rodrik information externality is essentially an incomplete version of infant industry argument translated into the language of Neoclassical market failure; it is an infant industry argument in that it recognises that the social benefit of starting a new activity in a developing country is higher than the private benefit for the 'pioneers', but it is 'incomplete' in that it ignores many types of inter-sectoral externalities, such as knowledge spill-over through inter-sectoral, rather than intra-sectoral, labour mobility; the development of supra-sectoral industrial commons' that can be used by many industries, rather than just one industry (see Rosenberg, 1969; Richardson, 1972; Andreoni, 2014; Andreoni and Chang, 2016; Andreoni, 2018).

Lin's NSE is a milder and inconsistent version of the infant industry argument; milder in the sense that it recommends deviation from comparative advantage only to a small degree ("imitate countries that are twice richer than you are") and inconsistent in that, once you accept that deviation from comparative advantage may be beneficial, it is not clear a priori whether a particular degree of deviation is necessarily better (on the 'second best' consideration) or even whether there is an objective way to know how much deviation is feasible before actually trying it.

Moreover, these theories have important limitations, which lead to policy recommendations that are often overly restrictive and sometimes even rather muddled.

Hausmann and Rodrik over-play intra-sectoral externalities in that they assume that, once the pioneer 'discovers' the relevant information, the imitators can acquire all the information from it. This is because they (without thinking) base their arguments the Neoclassical theory of production, in which all knowledge in production is perfectly transferrable. However, in reality, much of the knowledge about production discovered by the 'pioneer' would be firm-specific (and therefore useless even if it can be transferred) and/or tacit (and therefore cannot be transferred in the first place). If this is the case, the imitators cannot free-ride on the pioneer very much, which suggests that the information externality problem may not be a serious issue and that the lack of diversification in developing countries may have to be explained by something else.

Hausmann \& Rodrik under-play inter-sectoral externalities. They do not consider the impacts of infant industry promotion at the systemic level, which are especially important for the earlier phase of industrialisation. They ignore things like the creation of a modern industrial workforce (with factory-style work discipline and the habit of time-keeping), the introduction of modern management techniques, the accumulation of knowledge about exporting, and even the very practice of capitalist profit-making that come from industrial production experiences in general. These new workers and managers may transfer knowledge out of the sectors where they were first formed into other sectors. Given this, in the Hausmann \& Rodrik language, we could even say that all industrial firms (and not just sectoral 'pioneers') in less industrialised economies may be 'pioneers' that generate information externalities for the rest of the economy. This means that protecting or subsidising whole industrial sectors, and not just the 'pioneers' in those sectors, may be a good policy, unlike what Hausmann \& Rodrik suggest.

As for the GIF, it suggests a totally arbitrary criterion in industrial policy because it tries to have its cake and eat it at the same time - that is, adhering to the theory of comparative advantage while admitting the need to deviate from it. It recommends developing countries to follow countries with incomes that are about $100 \%$ higher (that is, twice), but where does this particular number come from? Why $100 \%$ ? Why not $150 \%$ ? Why not $500 \%$, for that matter? Indeed, empirical evidence shows that successful jumps have been 
far more ambitious than is suggested by the GIF - for example, the US per capita income was $2,000 \%$ that of Korea's, when the latter entered the steel industry in the mid-1960s (Chang in Lin \& Chang, 2009).

Also, the GIF implicitly assumes that an economy's 'ability to jump', so to speak, is already known - hence Lin's willingness to put a number ("about $100 \%$ higher") on the 'boundary of emulation'. However, very often, the whole point of economic development is that a backward economy doesn't really know what it is capable of until it tries new things as Hirschman beautifully put it, economic development "depends not so much on finding optimal combinations for given resources and factors of production as on calling forth and enlisting for development purposes resources and abilities that are hidden, scattered, or badly utilized" (Hirschman, 1958:5). It is because of this that countries like Japan, Korea, and Taiwan succeeded in entering industries that countries with incomes $500 \%, 1,000 \%$, or even $2,000 \%$ higher specialize in.

The Product Space approach, developed by Ricardo Hausmann and Cesar Hidalgo (Hidalgo \& Hausmann, 2009), which is supposed to provide practical guide to those who want to pursue the new mainstream approach to industrial policy (of Rodrik, Hausmann, and Lin), by charting the 'natural' path of industrial diversification by mapping the 'distance' between all exported products, also has some important theoretical problems.

First of all, the approach defines the proximity between products in terms of their classifications in international trade, which is according to the character of the final product, rather than in terms of the technologies used in their productions. This can lead to rather misleading understanding of the relationships between different industries. Similar products may be produced using very different technologies (e.g., the food processing industry uses a wide range of technologies, including refrigeration, fermentation, and packaging), while different products may be produced by using similar technologies (e.g., shipbuilding companies also produce oil-drilling platforms). ${ }^{4}$

Second, it is not clear whether related diversification, which is advocated by the Product Space approach, is necessarily better or easier than unrelated diversification. The 'miracle' economies of East Asia have diversified into all sorts of unrelated, as well as related, areas, while even many world-class companies are results of unrelated diversification Samsung used to produce textile and sugar before electronics, Nokia used to produce timber and rubber boots before electronics, and so on.

Third, being based on an ex post mapping, the Product Space approach does not recognise that the existing product space is not 'natural' and to a huge degree products of past industrial policies of the developed countries.

Fourth, even if there are 'natural' paths of progression between different products, industrial policy will still benefit countries if it allows them to travel along those paths more quickly than otherwise or to skip steps within the given path.

On top of all of these theoretical problems, there are all sorts of 'practical' issues that the new mainstream approaches to industrial policy do not consider. For example, Hausmann \& Rodrik (2002:19) proposes a hierarchy of policies on the basis of their information externality argument - 'government loans and guarantees' over 'export subsidies' over 'trade

\footnotetext{
${ }^{4}$ For example, a classic study of Nathan Rosenberg shows that, in the $19^{\text {th }}$ century, core technologies were share by rifles, bicycles, and sewing machines - products that fall into different groups in international trade classifications (Rosenberg, 1982; see Andreoni, 2014 for an historical review). More recent studies have revealed similar processes of inter-sectoral learning in the context of injection moulding and micro-tubing technologies across medical device, automotive and agricultural sectors (Andreoni 2018); or within the same sector between packaging machineries for food and pharmaceutical products (Andreoni et al., 2017).
} 
protection' - but these quickly fall apart when we consider the costs involved in the implementation of policies.

First of all, tariffs are the easiest tax to collect and therefore crucial for tax revenues in poorer countries with lower administrative capabilities. Given that it needs tax revenues in the first place in order to be able to provide subsidies, the government may have to engage in tariff protection to some extent before it can implement export subsidies.

Second, more targeted policies (whether government loans or firm-specific subsidies) may require more administrative capabilities, although this is not necessarily the case (Chang, 2011a). So, even if a policy tool is better in theory than another, the government may choose to use the inferior one because it is less demanding in terms of administrative resources. We are not advocating any particular policy here, but are pointing out that we need to pay attention to the implementation issues (e.g., financial and human resource demands, political considerations) before we decide on the superiority of particular types of policy based on theoretical models.

Since 2010, alongside the contributions by Rodrik, Hausmann and Lin discussed above, a number of new specific topics have been entering the debate. For example scholars are looking at the ways in which industrial policy must take into account the new patters of value creation, capture and distribution determined by global value chains (Milberg and Winkler, 2013; Chang and Andreoni, 2016; Andreoni, 2018); how new international rules are affecting countries' policy space (Andreoni et al., 2019); finally, the ways in which the financialisation of manufacturing companies is breaking the investment-profit nexus and impacting productivity and innovation (Lazonick in this special issue).

The analysis of these new dynamics affecting the ways in which firms work or countries compete in the international industrial and trade scenes are of critical importance. What is even more important is to recognize how these dynamics are intrinsically intertwined. For example, TNCs have been shaping the emergence and diffusion of GVCs, while have been also exercising enormous pressures in the redesign of international rules to protect their global value extraction practices (Andreoni et al., 2018). The increasing financialisation of manufacturing companies in both developed and developing countries are linked to institutional and regulatory changes affecting the functioning of the financial markets as well as changes in the functioning of major TNCs.

The next section will attempt to refocus the industrial policy debate around these structural interdependencies and related interdependent policy issues, and provide analytical grounding to the.

\section{Refocusing the industrial policy debate}

Since the mid-2000s, with the mainstreaming of the industrial policy debate, scholars have lost focus on the 'systemic/structural', 'micro-organisational' and 'institutional political economy' issues raised in the previous phases of the debate. Moreover, the intrinsic relationships linking these three issues is often undermined, linking to very partial analytical assessments of the industrial policy challenges countries face today in both developing and mature economies (Andreoni et al. 2018). To appreciate the extent of this problem, in Figure 1 below, we map the evolution of the debate discussed above along two main axes, namely the demand-supply axis and the global-national axis. The boxes reflects the analytical and policy focus featuring the four phases of the industrial policy debate discussed above.

The first phase of the debate (XVIII and XIX centuries) produced key seminal ideas in particular the concept of 'infant industry' - and positioned the industrial development and policy debate in solid political economy grounds. Classical economics also introduced key 
analytical concepts for analysing the production and sectoral dynamics, including the concepts of division of labour (Smith), laws of multiple (Babbage) and comparative advantage (Ricardo).

The second phase (early 1920s - 1960s) had the merit to develop and further elaborate some of the key ideas from the first phase - in particular the concept of 'infant industry' and frame them within a macro-meso national perspective. During this second phase, scholars and policymakers assigned importance to the inter-sectoral and structural issues locking industrial development (and re-development in Europe after the WWII). In particular, the idea that sectors and goods are intrinsically different was central. Thus, the importance assigned to manufacturing and its qualities - e.g. productivity, linkages, and multiplier effects - as well as the distinction between consumer and capital goods - e.g. emphasis on production technologies / machine tools. The recognition of this structural interdependencies and heterogeneity of the productive sector had critical policy implications in terms of industrial policy targeting and economic planning. This was also the period when the dependency theory elaborated the links between domestic development and different international trade regimes, thus, the foreign exchange rate constraint.

Building on the important analytical and policy arguments developed in the second phase, the third phase of the industrial policy debate (1970s - early 2000s) had the merit of bringing in a more 'micro-organisational', 'micro-structural' and 'institutional political economy' perspectives emphasising the role of competition, learning processes and institutions for industrialisation. The analysis of these micro-dynamics was intertwined with the study of the political economy of industrial policy, the role of the state and the way in which structural transformation generates conflicting interests whose composition impacts countries' industrial policy trajectories.

\section{Figure 1: Four phases of industrial policy debate: key themes}

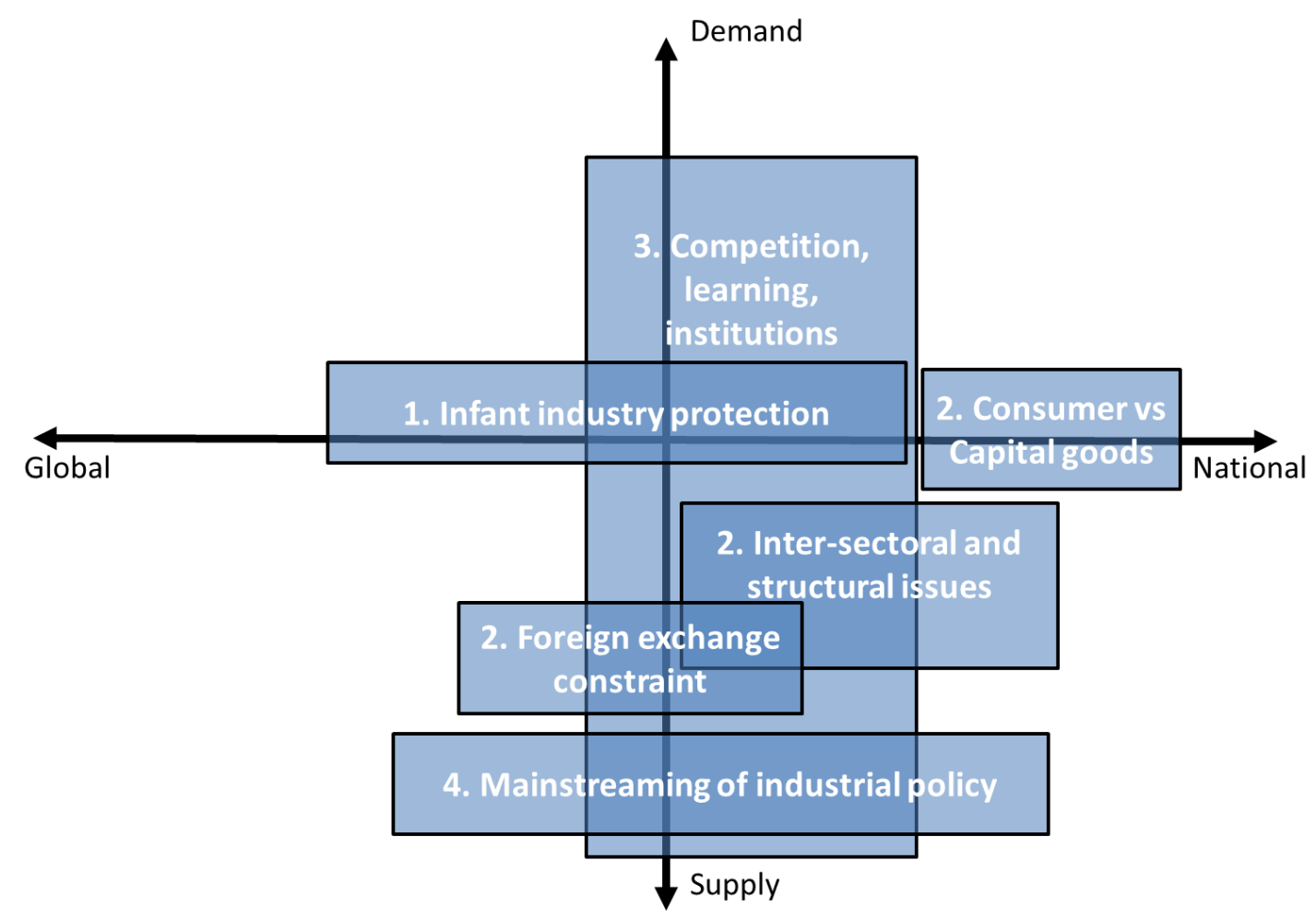

Source: Authors 
With the mainstreaming of the industrial policy debate, scholars have moved away from the consideration of major inter-sectoral and structural issues, and shifted towards micro-level supply-side discussions centred on the individual firm and its incentives in the market (more than its embeddedness in heterogeneous production structures and political economy contexts). This has led the majority of scholars to emphasise 'market failures', as in the case in which individual firms cannot capture returns from investments (externalities), or 'systemic failures', the latter mainly understood from an innovation system perspective (public goods underinvestment or failures in linking universities and firms in technological change processes).

On the contrary, little emphasis is given to the more fundamental 'structural coordination failures' arising from the many inter-sectoral and structural issues which still define the industrial transformation process. For example, developing countries are today told that a global value-chain industrialisation model is the only one possible, and indeed the most effective one. Little emphasis is given to the most fundamental challenges and risks associated with this model, and the persistent lack of local production systems development and value addition in developing economies, especially in Africa and Latin America (see Andreoni, 2019 for a critical review of this literature). Similarly, in the context of most developed economies, while 'systemic failures' have been increasingly recognised in the fourth phase of the industrial policy debate (Klein Woolthuis et al., 2005; Tassey, 2014; Dogdson et al. 2011; Wade 2012; Stiglitz and Greenwald, 2014; O'Sullivan et al., 2013), less emphasis has been given to sectoral constraints as well as technology push and demand pull dynamics (Soete, 2007; Laranya et al. 2008; Andreoni, 2016).

Similarly, with the mainstreaming of the industrial policy debate, the design of institutions and policies for industrialisation has been increasingly framed simply as a technical problem de-linked from any contextual and political economy considerations. As a result, in a number of countries, the return of industrial policies has mainly led to the importation of allegedly successful institutions and instruments without appreciating that institutions and instruments works only in specific contexts. This means that institutions and policies work because of they interact and complement other institutions and policy instruments which are in place in one given country, and that might be absent in others. Moreover, the functioning of these institutions and the enforceability of these policy instruments are not simply technical-design problems, they are also (and foremost in many developing countries) a political economy problem.

Despite some exceptions, the disappearance of a number of themes which were central in the second and third phases of the industrial policy debate has negatively impacted today's industrial policy thinking and practice. In particular, the effectiveness of industrial policy is critically dependent on the capacity of the state to deploy and strategically coordinate multiple policy instruments and institutions addressing complex interdependent dynamics. For example, to be effective, countries' strategic integration into GVCs also require policies and institutions focusing on firms' investments and financial markets regulation, alongside skills development and trade policies.

In the following sub-sections we disentangle three classical problems which remain central at the frontier of today's industrial policy. These are: (i) the strategic coordination of structural interdependencies arising in the process of industrial transformation; (ii) the challenges that countries face in building institutions and aligning policies to achieve industrial transformation; (iii) the importance of managing existing (and arising) conflicting interests and those political economy dynamics which ultimately affect the functioning of different institutions and the enforcement of policy instruments. 


\subsection{Structural Interdependencies, tensions and dualism}

Conventional economic growth models, and indeed the so-called New Structural Economics, are limited by their conceptualisation of the structure of the economic system and their understanding of structural interdependencies and dynamics. For example, let's look at the NSE approach whose aim is to advance a "neoclassical approach to study the determinants and dynamics of economic structure" (Lin, 2012:5). Within this framework, the interpretation of structures is limited as these are reduced to "relative abundance of natural resources, labour, human capital and physical capital" (Lin 2012:24). The upgrading of the industrial structure is treated as an aggregate growth process of upgrading of the factor endowment structure. Even when structural dynamics at a more disaggregated level are considered, the NSE framework remain rooted in the neoclassical idea that moving from a one sector-modelapproach à la Solow to a multi-sectoral approach is simply a matter of disaggregation and that comparative advantage in factor endowments is the main driver of structural change (Lin and Chang, 2009).

As pointed out by Pasinetti in a recent debate with Bob Solow: "The vision behind the aggregate model of traditional growth theory embodies a static, or at most a stationary, view of the economic system, and the reason is that it is inherently incapable of absorbing any change in time of the structure" (Pasinetti 2012:284 italics added). On the contrary, structuralist development ideas which informed the second and third phases of the industrial policy debate were rooted in a vision of the industrial world as "a permanently evolving economic system" (Pasinetti 2012:284).

According to this alternative vision of the industrial world, the economic system is composed by multiple sectors (and multiple production activities and technologies within them) linked by structural interdependencies operating at different levels of aggregation. In the process of structural transformation, these interdependencies tend to unfold in a disproportionate way across the sectors and production activities. This means that not everything changes at the same speed or at the same time. Different sectors (and their constituting activities) will expand at different growth rates, each of them following different structural cycles (Andreoni et al. 2017). The concept of structural cycle points to the fact that sector-specific technological and organisational changes at the micro-level will set the rate of change of the different economic sectors. As a result of these different speeds, certain traditional sectors will coexist with more advanced ones in the process of structural transformation ${ }^{5}$.

At early stages of industrial development, the development of one sector (or production activity within it) might remain locked by the inefficient scale of production of other related sectors, or the lack of sufficient demand or liquidity in the overall economic system. Thus disproportionate dynamics underlie structural tensions, that is, the continuous unfolding of constraints in the material/technological side of production, within and across sectors.

\footnotetext{
5 The principle of relative invariance postulates that "any given economic system subject to an impulse of force is allowed to change its original state by following an adjustment path that belongs to a limited set of feasible transformations. [The latter] is the consequence of both the characteristics of certain elements of an economic system that are taken as constant and certain patterns of interrelationships among the different components that are assumed as invariant in the structural specification of the system" (Landesmann and Scazzieri 1990:96). Thus, as soon as we introduce time, not only will we find that not everything changes at the same time but also that changes will unfold in an ordered way. Namely, the economic system will transform in a 'timedifferentiated' way, that is, according to a specific hierarchy of change (Andreoni and Scazzieri, 2014)
} 
Structural tensions and, thus, disproportionate dynamics within and across sectors, are generated by a number of factors: rigidities and indivisibilities in production structures (Young 1928; Kaldor 1985); complementarities among production tasks but also in consumption patterns (Young 1928; Perroux 1955; Hirschman 1958; Myrdal 1958; Dahmen 1989); horizontal and vertical externalities (Scitovsky 1954; Chenery 1959); adjustment lags, shortages and surpluses, differentials in the elasticity of demand and supply (RosensteinRodan 1957); disproportionate variations in technological coefficients and technological (or structural) unemployment (Pasinetti 1981; Balogh 1982).

Dahmen's (1989:138) treatment of structural tensions assigns particular importance to complementarities among production activities both in time and over time, that is, the fact that "economic success at certain stages [...] may lead to a depressive pressure in stages which are premature as long as the complementary ones are missing". For example, the introduction of the flying shuttles in the British textile industry in 1730s led to an acute shortage of yarn. The latter, in turn, first induced the introduction of innovative production techniques and, later, to overproduction problems, which were solved at the end of the century with the mechanical loom. For more recent examples of these structural tensions and resulting disproportionate dynamics we can look at the productivity paradoxes (slow productivity growth despite rapid technical change) appeared with the breakthrough of electricity in industry or the application of computers and robots in the 1980s (David 1990; Schon 2000; Rosenberg, 1982 and 1994; Andreoni, 2014).Thus, complementarities in time and over time are one of the key manifestations of these structural interdependencies (and tensions, when missing parts of the system constrain its development).

Another important feature that was central in the second and third phase of the industrial policy debate is also the fact that structural interdependencies tend to trigger circular and cumulative processes of development and underdevelopment (Myrdal, 1958; Kaldor, 1966; see Toner, 1999 for a review). Thus, structural dynamics not only are disproportionate across sectors of the same economy, they also tend to be non-linear across countries. At early stages of industrial development countries who manage to unlock a number of structural interdependencies and witness sectoral change at significant speed are also those who tend to experience exponential acceleration in their rate of growth. On the contrary, countries whose development is locked by unresolved structural tensions or countries experiencing premature de-industrialisation run the risk of entering vicious cycles of underdevelopment.

These cumulative processes arising from structural interdependencies often result in dualistic economic structures within and across countries - i.e. structural dualism. Luigi Spaventa (1960:1077) provided a general conceptualisation of dualism as 'a dynamic process of cumulative differentiation' (see also Prebisch's dependency theory 1950 and Dobb's historical analysis 1951). In his two-sector model Spaventa (1959; 1960:1077) investigates those "distortions which might occur in an unplanned growth process and which result in cumulative differentiation of two parts of an economic system [...] only separated by economic - not by physical - barriers". In particular the model attempts to identify those 'structural factors' that prevent: (i) the excess labour force from being absorbed by capital accumulation and (ii) a growth process from spreading across regions within the same country.

Three main structural factors are identified: firstly, the negative effect of inter- (or intra-) national trade on the size of the market for countries (regions) at early stages of manufacturing development. Secondly there is the issue of the imbalance between demand for new commodities and production capacity in the most disadvantaged region of a dualistic economy (the new commodities being produced by the most advanced region very often with little or no flexibility of technical coefficients). Thirdly there are problems related to 
technological discontinuities. As some countries have "been the leaders in the process of growth and, so to speak, the makers of technical progress", they "have not missed a single step in the technical evolution" (Spaventa 1959:433). In contrast, for others, "where growth has started later, often much later, there is no such gradual evolution [...] Newly introduced industries adopt modern and highly capital intensive methods of production and demand 'jumps' to some of the more advanced commodities produced in more developed countries at a still very early stage of development of the system" (Spaventa 1959: 433).

The three structural factors identified by Spaventa points to the existence of structural interdependencies linking demand and supply side dynamics, as well as both macro-meso and meso-micro issues. In particular, by following a certain path of sectoral development countries will also be pushed in certain technological development trajectories. Structural change and technological development are intertwined, because different sector will be able to produce and will require different technologies (Andreoni and Scazzieri, 2014; Andreoni, 2014; Andreoni et al., 2017; Andreoni and Chang, 2017). It is from this relationship that the makers of technical progress will emerge, especially in the area of production technologies.

Historically, early industrialisers not only developed a number of sectors first, but in doing so they also engaged in a gradual process of domestic technological development. In many cases this process also meant that these early industrialisers were those who managed to acquire dominant positions in the manufacturing of production technologies first.

For example, in 1910, 82.4\% of the world production of machine tools was concentrated in three countries: the US (50\%), Germany $(20.6 \%)$ and the United Kingdom (11.8\%). In 1945, the situation was largely unchanged, although the USSR entered the machine tools industry global race, reaching $10 \%$ of world production (Rosenberg, 1963). Late industrialisation in East Asia changed this global landscape and saw a number of catching up economies engaging in domestic processes of technology acquisition and gradual technological development, also in production technologies. In 2010 one-third of world machine tool production was concentrated in China and another third in the Euro area (the three major producers are Germany with $43.5 \%$, Italy with $23 \%$ and Switzerland with $11 \%$, of total European output; CECIMO database) ${ }^{6}$. Meanwhile Japan still controls $14 \%$, followed by the Republic of Korea with $7 \%$ and Taiwan with 6\%. As of 2010 the United States accounted for only $4 \%$ of global production. A full $66 \%$ of the machine tools produced in 2010 were consumed in Asia, 21\% in Europe and 13\% in America. In 2011 China alone accounted for $45 \%$ of world machine tool consumption. It was followed by three major net exporters (Japan, Germany and Italy which consumed 9, 8 and 4 percent respectively) and one major importer, the United States, with an $8 \%$ share in world machine tool consumption (Andreoni and Gregory, 2013).

The machine tool industry - as the 'mother industry' in which production technologies are developed for itself and the other economic sectors, especially agriculture and services - played a key role in the sectoral change and technological transformations of early and late industrialisers. The special properties of this manufacturing industry (Andreoni and Gregory, 2013), alongside other distinctive properties of manufacturing (Andreoni and Chang, 2017), can only be appreciated from a perspective which takes full consideration of the role that structural interdependencies play in industrial development. Different sectors requires different production technologies and their competitiveness derives largely from them - i.e. production costs, process efficiency, product quality standards etc.. Moreover, as

\footnotetext{
${ }^{6}$ The United States went from 26.6 per cent in 1980 to 11.7 per cent of world machine tool production in 1995 (the United Kingdom lost its major role before the 1980s, and in 1995 accounted for less than 3 per cent of world production). In contrast Japan and Germany followed the opposite trend during the same period, going from 14.3 to $23.5 \%$ and from 17.6 to $22.6 \%$ respectively (Andreoni and Gregory, 2013).
} 
these are the only technologies which are required to produce products but also to produce other technologies, they occupy a special node in the system of structural interdependencies of an economic system.

The consideration of structural interdependencies in this section has identified three set of issues so far. First that the economic structure is made of a complex system of interdependencies linking demand and supply, as well macro-meso-micro dimensions. Second, that change unfolds in a disproportionate fashion and that therefore structural interdependencies generate structural tensions and dualism across countries and regions in the process of development. Finally, that sectoral and technological development are intertwined, and therefore only a pool of successful late industrialisers have managed to learn how to develop 'production technologies' vis a vis simply 'using' them. Figure 2 provides a visual representation of these structural interdependencies.

\section{Figure 2: Structural interdependencies}

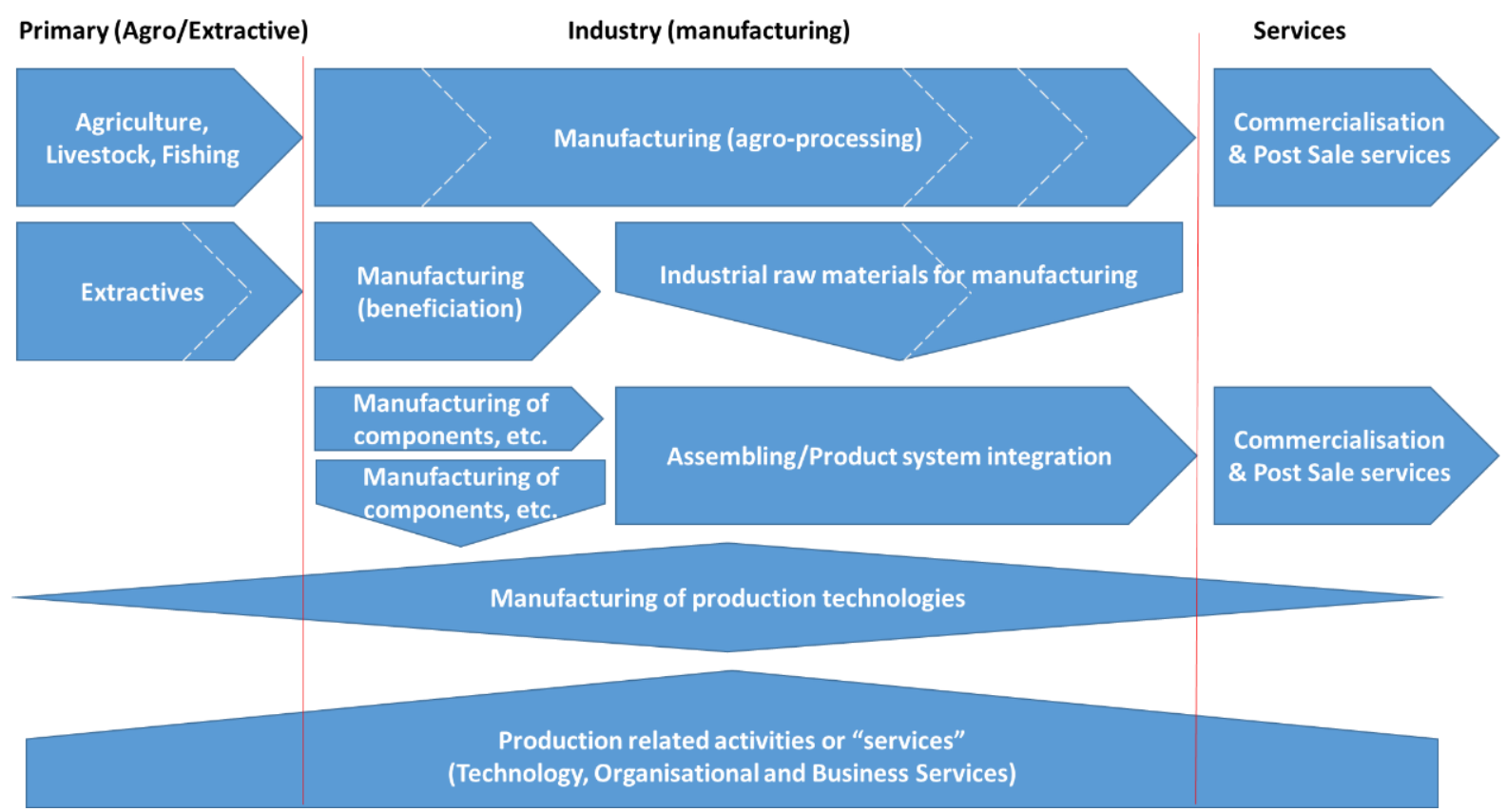

Source: Authors

In such complex economic systems, where the factors of production are 'interdependent in use but dispersed in ownership' (Abramovitz, 1986: 402), effective structural change may require coordinated changes in many components of the economy. This is because those who control individual components may be unable to initiate and achieve the change, as they may not possess all the interdependent factors may suffer from a lack of these factors and/or from strategic uncertainty as to the behaviour of the other relevant agents. Hence, the need for strategic coordination by some central agent (or regional government, depending on the policy target and governance model) for an economy-wide change to happen.

Such coordination, however, should not be seen as merely coordinating a shift from one equilibrium position to a higher level one, although such a formulation may be useful for certain purposes. This view assumes that all the relevant agents know all the possible 
equilibria and can find out which of them is the best outcome (at least in the probabilistic sense). In such a formulation, the only obstacle to change is the difficulty of simultaneous movement.

However, the problem is exactly that we are not aware of the full range of possibilities, not to speak of being unable to tell which of them is the best (Chang and Andreoni, 2016). Thus seen, structural change as defined here requires much more than choosing from a preexisting choice set. It requires formulating the choice set itself, namely, providing a vision for the future. And the state, as the central agent, can play an important role in providing such a vision. Indeed, as Albert Hirschman famously stated "if the economy is to be kept moving ahead, the task of development policy is to maintain tensions, disproportions and disequilibria. That nightmare of equilibrium economics, the endlessly spinning cobweb, is the kind of mechanism we must assiduously look for as an invaluable help in the development process" (Hirschman 1958:66).

\subsection{Institutions building, bottlenecks and policy alignment}

The strategic coordination of structural interdependencies require the government setting up different types of institutions and deploy a variety of policies (Chang and Andreoni, 2019; Andreoni, 2016) ${ }^{7}$. It is through these institutions that industrial policy can be designed, but also implemented and enforced. Exactly because policy makers will have to rely on different institutions and policies, the first challenge they face is not simply to build institutions and policies, but to do so in a coherent manner. This means developing institutional complementarities and aligning policies in time.

At the same time, structural transformations of the economy induce changes in institutions or, as stressed by Kuznets (1973:247), economic growth will demand "institutional and ideological adjustments" (see Andreoni and Chang, 2017 for a discussion). The lack of these institutional adjustments can block the structural transformation of the economy or divert the economy along a non-desirable pathway. Thus, the second major challenge policy makers face it to remove institutional bottlenecks as they unfold along the industrialisation pathway. This is particularly critical as by removing these bottlenecks and building up new (and different types of) institutions, new policy instruments will become available, implementable and enforceable.

The third major challenge policymakers face results from the former two. Specifically, it derives from the fact that every time new adjustments in institutions or policy are introduced in response to structural change, policy makers will have to find a new coherent way of integrating and aligning them within the existing institutional and policy mix. Indeed industrial policy effectiveness will depend critically on the extent to which institutions and policy instruments are aligned over time to the structural cycles - technological and organisational changes - of the economic sector or activity they target (see Andreoni et al. 2017 for an in-depth case of structural cycle and industrial policy alignment).

Thus, industrial policymakers have three main related challenges in front of them: (i) building different types of institutions and implementing policies in a coherent manner in time; (ii) manage the interplay between structural transformation and institutional change, in particular addressing institutional bottlenecks; (iii) as a result of the former two challenges,

\footnotetext{
${ }^{7}$ There is no agreed definition of institutions among old and new institutional economics scholars. For an indepth analysis of these issues see Chang, 2007b and 2011b; Chang and Andreoni, 2019.
} 
making sure that the introduction of new institutions and policies reinforce complementarities among them and avoid situations in which they contradict or undermine each other.

Let's then look at each of these challenges by addressing key industrial policy questions.

\subsubsection{Institutions building: is there a 'forms-functions formula'?}

Historically countries have relied on a variety of institutions for their industrialisation, thus there is no institutional blue print for industrialisation which governments can paste and copy. Attempts of these paste and copy exercises have been largely unsuccessful as they do not take into account the contextual and political economy feasibility of certain institutional arrangements. Having said that, governments can learn from analysing the variety of institutions (and their distinctive features), that successful and unsuccessful countries deployed at different stages of their industrialisation path.

Institutions for industrialisation can take different forms, let's say a certain property rights regime or a certain governance model, and each of these institutions can perform one or more functions. In fact the same institutional functions may be fulfilled by different institutional forms, the latter being developed in different historical contexts.

The distinction between forms and functions is critical in understanding the variety of institutions in context. It also avoids governments to become fixated with institutional forms which emerged out of specific country contexts and historical trajectories - let's say institutional forms developed within the US-UK variety of capitalism.

However, this distinction does not lead to an optimal 'forms-functions formula' for industrialisation. On the contrary, as stressed by Chang (2007a:23): "[a]t the very general level, we may say that there are certain functions that institutions have to serve if they are to promote economic development, and that there are certain forms of institutions that serve these functions the best. However, the difficulty is that we cannot come up with an agreed list of the 'essential' functions nor an obvious match between these functions and particular forms of institutions".

Therefore, policy makers should focus on the design and implementation of the most appropriate institutional forms-functions formula for the context and the stage of development they face. In particular, they have to make sure that institutional complementarities are developed and that policies are as much as possible aligned. So for example, trade policies promoting exports should support micro-level production efficiency, organisational capabilities and financial access to invest in scale-efficient processes.

In the definition of this appropriate formula, we believe that functions should be given some prominence over forms. The reason being that functions come out from specific structural requirements in the productive sector, so for example productive capabilities development or industrial financing. Chang and Andreoni (2019) provide an institutional taxonomy distinguishing six types of institutions performing critical functions (and taking different forms) in the industrialisation process.

\subsubsection{How 'institutional bottlenecks' unfold in industrial development?}

Section 3.1 stressed how industrialisation is a structural transformation process in which structural interdependencies among different parts of the economic systems can generate structural tensions. Each of these structural tensions will demand adequate institutional responses and policies. The lack of a certain institution performing certain specific functions - i.e. institutional bottleneck - can turn these structural tensions in unsurmountable constraints. On the contrary, institutions building can turn structural tensions in opportunities for development. 
Probably the most well-known example of an institutional bottleneck is the one provided by Alexander Gerschenkron (1962: especially chapter 5). A century ago, when Germany was attempting to catch up with Britain, production technologies available were more capital- and scale- intensive than those that had been discovered when Britain underwent its first round of industrialisation some fifty years before. Thus, Germany had to develop new institutional instruments for which there was "little or no counterpart in an established industrial country" such as coordinated investments, vertically integrated production units, and a financial sector which was transformed in its institutional form and functions.

A similar transformation of the banking sector on the German model was also a key factor in the industrialisation of Italy between 1881 and 1913. The two main institutional innovations of German banking imported in Italy, by the Banca Commerciale Italiana established in 1884 under German leadership and with German capital, were (Gerschenkron 1955:375): firstly, "to maintain an intimate connection with an industrial enterprise and to nurse it for a long time before introducing it to the capital market, which as often as not meant placing its stock among the bank's own clients"; secondly "to discipline production of industrial branches, which bland phrase meant reduction or abandonment of competition in favour of various monopolistic compacts".

Thus, structural change calls for institutional adjustments, while the lack of these adjustments leads to institutional bottlenecks. However, introducing new institutions and policies or simply adjusting the existing ones in response to one arising structural tension is not sufficient. Institutional complementarities and policy alignment must be reconstituted over time.

\subsubsection{Why are inter-temporal institutional complementarities and inter-temporal policy alignment important?}

Institutions and policies for industrialisation set the conditions for developing productive capabilities as well as the incentives to deploy them in a productive way and further develop their depth and breath. The nexus between capabilities and incentives is indeed central in many of the institutions and policies supporting industrialisation (Lall, 2001; Chang and Andreoni, 2019). The introduction of new institutions or policies change the critical nexus between incentives and capabilities, thus affecting productive organisations strategies.

By looking at the way in which new institutions and policies change the balance of incentives and affect capabilities among productive organisations, policy makers can also assess the extent to which institutional complementarities have to be re-established and policies re-aligned. The challenge for policy makers here is that institutional and policy changes always affect the distribution of resources among different groups. Resistances to change might be so strong that they can undermine the results that the new policies and institutions aim to achieve. This is why institutions for industrial restructuring like recession cartels might play a key complementary role in the process of structural transformation, especially in addressing the conflicting interests among organisations (including among groups within the government) (Chang, 1994; Chang and Rowthorn, 1996).

The fact that aligning, changing and re-aligning institutions and policies involve these conflictual dynamics, points to the fact that industrial policy is an "institutional political economy" process and that institutional change cannot be understood simply as a technical process.

\subsection{Managing conflicting interests and government organisational capabilities}


In the previous sections 3.1 and 3.2, we pointed out how the likelihood and the speed of catching up depend on a country's capacity to overcome the structural tensions as well as the related institutional bottlenecks which unfold at different stages of industrialisation. However, as stressed by Dahmen (1989:111), '[a] retardation in eliminating a structural tension [...] may be caused by institutional factors such as resistance of groups with vested interests, monopolies, government regulations and legal framework ${ }^{8}$.

During the second phase of the industrial policy debate, Michael Kalecki (1976) was among the first scholars to frame industrial development as a political economy process in which different groups (and sub-groups within them) organise their power to protect and promote their interests. In his analysis of underdeveloped economies the supply bottleneck in the agricultural sector is in fact determined by the class structure of the rural area. In a Marxian fashion, Kalecki also pointed to the existence of the capitalist and the working classes as well as 'intermediate' classes whose conflicting interests and power will be reconfigured in the structural change process.

The consideration of different units of analysis - i.e. classes (or groups), sub-groups and intermediate classes - makes possible to identify the different interest groups (and subgroups) involved in the industrialisation process and the extent to which their interests are or not aligned to structural change. In the classical political economy framework, these groups included the landlords, the financiers and the industrialists, and different industrialists operating in different manufacturing industries.

Historically, countries with a strong landlord class or a strong financial capitalist class have always found it difficult to implement good industrial policy, as those classes want policies that may be detrimental to productive capacities development. One such prominent example is the US landlords in the South up till the Civil War constantly putting pressure for free trade despite the fact that it would have deterred the development of the country's manufacturing sector. In the more recent period, we have seen the strong financial capitalist classes of the UK and Brazil wanting policies that lead to overvalued exchange rates, thereby destroying large swathes of their export-oriented manufacturing industries.

In the African context today, the private sector is characterised by a limited number of industrialists capable of investing in a competitive way, and a plurality of big players involved in trading activities, construction and services. These latter are powerful players whose interests are in conflict with the ones of the industrialists and other SMEs, for example with respect to the competition for the internal market. Given the lack of productive capacities, importing produces from other countries tend to be cheaper and less risky. Moreover, investments in productive activities is perceived to be riskier than operating in the construction or services industries. As a result financial capital and interest rates favour mostly the latter sectors, and investments in productive activities remain limited in scale and scope. Finally, given the lack of medium size companies, the few big industrialists are able to squeeze their local supply chains which remain disarticulated and uncapable to reach efficient scale (Andreoni, 2019)

However, all of this does not mean that a country is bound by its history or lack of an industrialist class. New political coalitions can be built and policies changed. For example, in the late $19^{\text {th }}$ century, Bismarck managed to make the landlord class (the Junkers) accept high tariff protection and other industrial policy measures for the emerging heavy and chemical industries by providing it with its own protection too - in the so-called 'marriage of iron and rye'. For another example, in 1860, the Northern manufacturing states of the US established their national hegemony by establishing the Republican Party, which brought on board the

\footnotetext{
${ }^{8}$ On this point see also Abramovitz's (1986) notion of technological congruence and social capability.
} 
Western states, traditionally in favour of free trade, by offering them free distribution of public land (embodied in the Homestead Act of 1862) - and eventually winning the Civil War.

The traditional categories of the classical political economy framework remained almost the same during the second phase of the industrial policy debate, although in different contexts it became increasingly clear how in the process of structural change conflicting interests within traditionally defined groups are equally important as those arising between them. For example, as Landesmann (1992:246 italics added) stresses in the specific case of Scandinavian countries, "[s]ocial corporatism has the problem not only of finding a consensus (or a mode of conflict resolution) between classes, but also of building on a consensus within classes. At least it has to show that it can successfully provide the framework to mediate between different segments of the same class and thus avoid open conflict" (see also Chang 1994b). This is a particular critical insight in the development of new units of analysis to study the political economy of industrial policy.

Since the 1990s, with the increasing transformations of the worlds of production, in particular the fact that geographical and sectoral boundaries are blurring, the sector-based unit of analysis of the classical political economists are becoming obsolete and unable to map out the conflicting interests expressed by different interest groups and sub-groups within and across countries. For example, regional value chains connect sectors in different countries and express interests which are beyond their individual countries of reference. This is particularly the case of regional blocks with high degree of supply chains integration like the EU. Moreover, within the same sector, along the value chain, firms of potentially different size and with different shareholders and corporate governance structures are expression of completely different interests (sometimes conflicting even more than across sectors) and might have different organisational power. Finally, even within the same organisations, different corporate governance regimes can allow processes of value capture or financialisation which are detrimental to different groups within the organisations in different ways (Andreoni, 2018).

Policymakers play a key role in managing this complex web of conflicting interests and organise interests around a certain development vision. The conflict resolution function of the state is indeed related its entrepreneurial function. This is because conflicting interests will be more likely aligned if the government provides "a focal point around which economic activities may be organised in times of major economic change" (Chang 1994b:299). The problem of providing focal points (i.e. providing an overall vision to orientate individual economic actors) by aligning a series of policy measures over time is not simply a problem of shifting the economic system from one configuration (or equilibrium point, in neoclassical terms) to another. Instead, if we fully embrace the idea of a continuous interplay between structural economic dynamics and institutional transformations, the economic system will be in a never-ending condition of disequilibrium. Within this framework industrial policies will be necessary for addressing at different stages of development (not just underdevelopment!) various structural tensions, institutional bottlenecks and dualisms.

Government institutions are themselves expression of different interests, partially reflecting the broader political economy context in which they operate. Therefore, as much as managing conflicting interests among groups (and sub-groups) within the broader society, governments will face the challenge of managing conflicts within themselves. In particular, this means that governments will face the challenge of aligning institutions and policies run by different ministries, departments, agencies (MDAs) - operating at different levels, from the regional to the national level, each of them expression of different segments of the society (Stiglitz, 1996; Chang, 2011a; Andreoni, 2016). 
In many developing countries, political processes of consensus and clientelist network building have often led to the proliferation of MDAs, with significant problems of duplications. In some extreme cases these MDAs are not simply ineffective, instead they can become rigidities in the government institutional structure and strong forces resisting any change. Several institutional solutions have been adopted to address these competing and conflicting dynamics across MDAs and develop government organisational capabilities.

First, mechanisms to coordinate their actions, whether through some intellectual exercises (e.g., indicative planning, foresight exercise) or through organisational structures that make coordination easier (e.g., some coordinating super-ministry, such as France's Planning Commission or Korea's Economic Planning Board [EPB]) have been introduced.

Second, the industrial policy mandate has been moved to the highest policy level, that is, the country's prime minister or president and the coordinating organisations - superminitry, national councils, etc. - have been put under the chairmanship of the president.

Third, in order to coordinate industrial policy packages beyond policy silos, budgeting procedures and related incentives in budget allocation have been revised to pool resources and exploit policy complementarities. For example, despite the fact that in many countries the budget allocated to the Ministry of Industry is relatively small, there are various budgeted resources whose use could be aligned with industrial policy and productive capacity building objectives. For example, local contents policies and strategic public procurement can open important market opportunities for domestic companies. While these resources are not directly controlled by the Ministry of Industry, they can be indirectly channelled towards industrial policy goals. In some other cases, budgets can be more directly focused. This is the case of the education budget and the emphasis given to different types of skills at different stages of industrial transformation.

The effective interaction among the different MDAs within the government is often one of the key ingredients in successful industrial policy implementation and enforcement. The reason being that without this 'organisational capability' within the government, the different MDAs might pursue mis-aligned policy initiatives and interests.

\section{The Industrial Policy Package Matrix: A framework for strategic coordination?}

Industrial policy is an "institutionally structured process" (Chang, 1994b) dealing with three fundamental set of issues - structural interdependencies, institutions building and policy alignment, and conflict management. As discussed in section 3, what makes the industrial policy process particularly complex is that these three set of activities are interdependent and that to address key coordination challenges - arising structural tensions, institutional bottlenecks and policy misalignments, and conflicting interests - governments will have to rely on multiple policies.

The following description by Alice Amsden of the way in which South Korea dealt with these coordination challenges is a vivid summary of the set of issues raised in section 3 .

While Korea was building a chemical plant to international standards, the level of those standards was raised, so the plant had to be redesigned in mid-stream — an expensive proposition. Then when Korea began selling chemicals in world markets, the big chemical companies began 'dumping' — flooding the market to reduce prices and drive Korea out. So the government granted some subsidies to the chemical plant to keep it in

\footnotetext{
${ }^{9}$ This section and in particular the Policy Package Matrix tool draws from and develop (Andreoni, 2016). For an application of this tool to policy debates and practice see the UNCTAD World Investment Report 2018.
} 
business. When Korea's shipyard opened, world demand collapsed and Korea was stuck with an expensive inventory of unsold ships - the quality of the first generation of ships was understandably poor. The shipbuilder, Hyundai Heavy Industries, bought the unsold ships from itself and established a merchant marine. Then the Korean government stepped in and decreed that all crude oil sold to Korea had to be delivered in Korean-made ships. This was like an orchestra: all the instruments fit together. (Alice Amsden, interview with van der Hoeven, in van der Hoeven 2008: 1094; italics added)

This quote, alongside other analyses of the East Asian experiences (see Wade, 1990; Chang, 1994a; Stiglitz, 1996) and todays' industrial policy across major global players (Andreoni, 2016), point to the fact that industrial policy is not about one policy, or one institutions. It is indeed about the design, implementation and enforcement of "packages of interactive measures" and their strategic coordination. These packages of policies allow government to provide productive organisations with the most effective mix of incentives and capabilities for developing industrial competitiveness.

For example, as stressed by Chang (2011a, 100), "In East Asia, free trade, export promotion (which is, of course, not free trade), and infant industry protection were organically integrated, both in cross-section terms (so there always will be some industries subject to each category of policy, sometimes more than one at the same time) and over time (so, the same industry may be subject to more than one of the three over time)." Similarly, in the context of Scandinavian countries, Landesmann $(1992,242)$ stresses how these countries adopted an, "interesting mix of both defensive and constructive policies."

Strategic coordination of industrial policy packages is a complex and dynamic process. It is complex because it involves the coordination of different institutions and policy instruments, each of them targeting directly one specific policy domain - let's say skills training, or industrial finance - and, indirectly, impacting several others policy domains let's say technology absorption and scale efficient investments. It is also dynamic because, as discussed in section 3, to maintain institutional complementarities and policy alignment, the government will have to adjust the package of interactive measures over time (Andreoni et al, 2017 provides an in-depth case study of this policy re-alignment in the Emilia Romagna context).

Each policy domain represents a relatively homogenous set of instruments or institutions targeting one part of the industrial system. For example, R\&D credit, standardisation policy and public technology intermediaries are all instruments/measures/institutions targeting the "Innovation and Technology Infrastructure" of the industrial system. While industrial policy generally relies on supply side instruments, there are also policy domains including demand-side type of instruments such as procurement policy and external market development policies.

Each industrial policy and institutions can target and operate at different levels of the economy. Some policy instruments are tailored as sector-specific measures, and can also target specific firms within those sectors (SMEs in the food supply chain for example). There are then policies which are focused on the manufacturing system as a whole, in particular those targeting export promotion or development of technology platforms which are critical for manufacturing development (e.g. capabilities in machine tools). Some industrial policy instruments can be more openly focusing on cross-sectoral targets in the industrial system, for example those targeting better integration between agriculture and manufacturing industries. Finally, there are policies which are more macroeconomic in nature, such as interest rate and exchange rate policies. Despite the fact that they will affect the overall economy, this does not mean that they will affect all sectors of the economy in the same way. A certain interest rate policy will affect sectors with different degrees of capital intensity differently.

Finally, each industrial policy in a certain policy domain and targeting a certain level of the economy can be implemented and enforced through the deployment of different policy 
governance models and organisations. Depending on the way in which a country frames its industrial policy and the different actors involved in its design, implementation, and enforcement we can have different policy models. Countries adopting a top-down model rely on centrally-planned packages of industrial policy whose implementation and enforcement is mainly done by national or federal government institutions. On the contrary, in a bottom-up model, a plurality of regional or state actors within nations and federations orchestrate multiple industrial policies.

Although this "bottom-up" governance model allows for more selective place-based interventions and introduces a certain degree of flexibility in policy action, countries without diffused institutions with government organisational capabilities cannot afford it. Also, multiple decentralized initiatives may lack coherence or might conflict and overlap making the industrial policy package ineffective. In order to avoid this industrial policy coordination problems, governments which can rely on well-developed institutional settings tend to adopt a multi-layered policy governance model combining top-down and bottom-up policy features. So for example, governments carefully select those policy domains for which it is important to have a place-based differentiated approach, and those where national level coordination is required to avoid fallacy of composition problems.

Figure 3 shows how the consideration of these three set of issues - namely, policy domains, levels of policy interventions, policy governance models - within an integrated framework make possible to visualise packages of interactive industrial policy instruments and institutions as well as identify critical coordination problems. Figure 3 shows how the consideration of these three set of issues - namely, policy domains, levels of policy interventions, policy governance models - within an integrated framework makes it possible to visualise packages of interactive industrial policy instruments and institutions as well as identify critical coordination problems.

In Figure 3 we present a Policy Package Matrix framework to analyse industrial policy packages. The matrix is structured around two main axes. The horizontal axis lists a number of key 'policy domains' within an industrial policy package. These policy domains are divided into two subsets: supply-side and demand-side policy domains, depending on the nature of the policy instruments used. So, for example, policy instruments targeting investments in skills development or production capacity expansion are listed in the supplyside domain A public procurement policy or a policy aimed at entering international markets are listed in the demand-side domain. The policy domains listed in policy matrix include all instruments and targets of industrial policy that have been used. The vertical axis pertains the remaining two issues discussed above, that is, the policy governance model and the level of policy intervention. First, it distinguishes between policies implemented at the level of the central authorities - national or federal - and at the sub-government levels regions or state. Each of these government authorities can target different policy domains by intervening at different levels. They can target a specific sector, several interrelated manufacturing sectors, or the entire industrial system. 
Figure 3 Policy Package Matrix

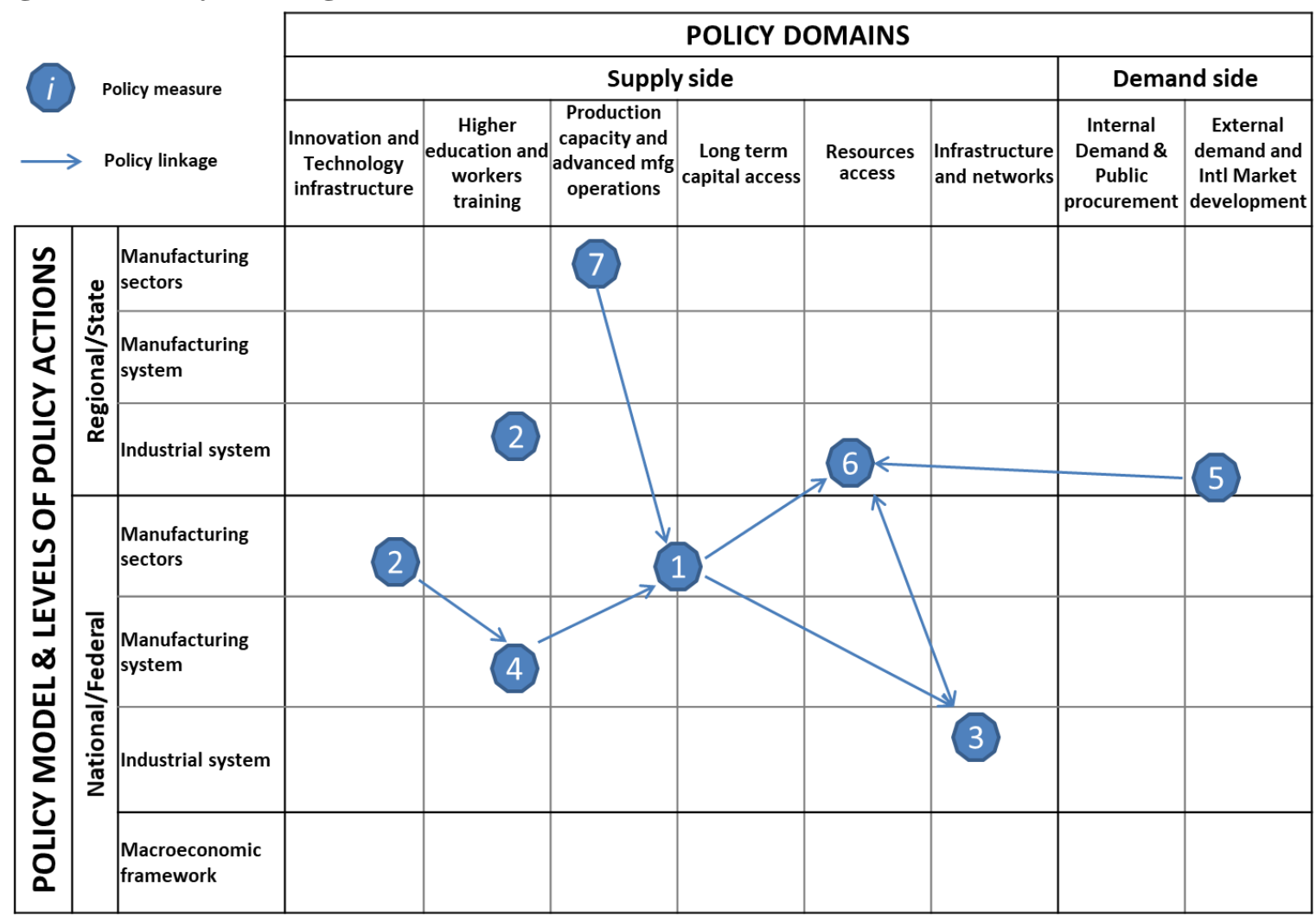

Source: Authors, adapted from Andreoni 2016

The Policy Package Matrix is a useful analytical and policy tool in five main respects (see Andreoni, 2016 for a broader discussion and review of the model).

First, a policy matrix allow for mapping out and clustering the different policy instruments a national government (and eventually its different sub-regional governments) is implementing. In doing so policy matrixes provide a good basis for reflecting upon the degree of targeting of each policy instrument - levels of policy interventions - as well as the main policy domains that the government is investing on.

Second, the policy package matrix helps in identifying the existing as well as potential interactions linking the different policy instruments implemented and enforced by different institutions - MDAs - across different policy domains. This also means understanding the 
distribution of the different instruments and resources across MDAs, and the extent to which more institutions operate in the same policy domain.

Third, by revealing the presence of policy interactions within the overall policy package, through the policy package matrix it is possible to identify potential policy misalignment or trade-offs which would remain unnoticed otherwise. These misalignments might also be related to lack of coordination or duplication among MDAs, as well as the fact that the instruments adopted by one government are not aligned with those left by previous governments (alignment over time).

Fourth, the policy package matrix suggests how countries can adopt different packages of industrial policy measures and can coordinate different policy instruments either to have a combined effect on the same target or to manage potential trade-offs among different goals. For example, education policies can be aligned to labour market reforms to improve workers' conditions. Technology policies can also be aligned to trade policies or public procurement measures supporting domestic industrial sectors development.

Fifth, by visualising the linkages across policy domains and instruments, the policy package matrix stresses how the effectiveness of a single policy measure depends on its linkages with other policy measures acting upon the same companies, sectors and specific institutions. This implies that the policy effectiveness of a certain instrument might be improved by both/either using the instruments more effectively and/or by changing or introducing other complementary instruments. The combined effect of different policy instruments tends to be different from the one that the government can achieve by the independent implementation of the same policy measures.

\section{Concluding remarks}

The renewed interest in industrial policy and the more open discussion in academic as well as policy circles are important turns in the long history of industrial policy. However, with the recent mainstreaming of industrial policy, the academic and policy debates seem to have lost the depth and the breadth which had characterised earlier phases of the debate. In a Schumpeterian fashion, the paper presented a brief 'history of economic analysis' of industrial policy, and focused on a critical review of the current industrial policy debate. This review has provided a long-term analytical and historical perspectives to today's industrial policy rationales, including new tools like the product space and the GIF approach.

Building on this analysis, we proposed to refocus the debate around three critical issue: (i) the strategic coordination of structural interdependencies arising in the process of industrial transformation; (ii) the challenges that countries face in building institutions and aligning policies to achieve industrial transformation; (iii) the importance of managing existing (and arising) conflicting interests and those political economy dynamics which ultimately affect the functioning of different institutions and the enforcement of policy instruments.

Drawing on contributions from the second and third phases of the industrial policy debate, we have provided an alternative analytical categories for bringing industrial policy really back. In particular, distilling insights from successful industrialisation experiences, we have focused on the importance of rethinking industrial policy as packages of interactive measures operating across different policy domains and levels of interventions, and implemented and enforced through a variety of institutions - policy governance. From this perspective, and with specific reference to the analytical and policy tool of the Policy Package Matrix, we discussed how strategic coordination of these packages of interactive measures can be achieved. 
Against the current mainstreaming of industrial policy, the paper has emphasises why and how 'structures', 'institutions' and 'policies' are still today at the frontiers of industrial policy. Their specific manifestations in different historical contexts can be better captured through in-depth comparative political economy analysis, once the guiding analytical categories have been reintegrated into today's mainstream industrial policy debate. This paper is a contribution in this direction, and a reminder of the fact that after a few decades in which industrial policy was a taboo, today's mainstreaming of industrial policy is equally a potential threat to the return of industrial policies.

\section{References}

Abramovitz, M. 1986. Catching Up, Forging Ahead, and Falling Behind, Journal of Economic History, XLVI, 385-406.

Amsden, A. 1985. The State and Taiwan's Economic Development, in P. Evans, D. Rueschemeyer \& T. Skocpol (eds.), Bringing the State Back In, Cambridge, Cambridge University Press

Amsden, A. 1989. Asia's Next Giant, New York, Oxford University Press

Amsden, A. and Singh, A. 1994. The optimal degree of competition and dynamic efficiency in Japan and Korea, European Economic Review, 38: 941-951.

Andreoni, A. 2014. Structural Learning: embedding discoveries and the dynamics of production, Structural Change and Economic Dynamics, 29,58-74.

Andreoni, A. 2016. Varieties of Industrial Policy: Models, Packages and Transformation Cycles, in Noman, A. and Stiglitz, J. (eds.), Efficiency, Finance and Varieties of Industrial Policy, New York, Columbia University Press, 245-305.

Andreoni, A. 2018. The architecture and dynamics of industrial ecosystems: diversification and innovative industrial renewal in Emilia Romagna, Cambridge Journal of Economics, 42, 6.

Andreoni, A., 2019. A Generalized Linkage Approach to Local Production Systems Development in the Era of Global Value Chains, with special reference to Africa, in Noman, A. and J. Stiglitz, eds., Quality of Growth in Africa, Columbia University Press.

Andreoni, A. and Gregory, M. 2013. Why and How Does Manufacturing Still Matter: Old Rationales, New Realities, Revue d'Economie Industrielle, 144,4, 21-57.

Andreoni, A. and Scazzieri, R. 2014. Triggers of Change: structural trajectories and production dynamics, Cambridge Journal of Economics, 38(6), 1391-1408.

Andreoni A. and Chang H.-J. 2016. Industrial policy and the future of manufacturing, Economia e Politica Industriale, 43,4,491-502.

Andreoni, A., Frattini, F. and Prodi, G. 2017. Structural Cycles and Industrial Policy Alignment: The private-public nexus in the Emilian packaging valley, Cambridge Journal of Economics, 41,3,881-904.

Andreoni, A. and Chang, H.-J. 2017. Bringing production and employment back into development, Cambridge Journal of Regions, Economy and Society, 10,173-187. 
Andreoni, A., Chang, H-J, Konzelmann, S. and A. Shipman. 2018. The Dynamics of Economic and Industrial Renewal in Mature Economies, Cambridge Journal of Economics, 42, 6.

Andreoni, A. and Tregenna, F. 2018. Stuck in the Middle: Premature Deindustrialisation and Industrial Policy, IDTT Working paper 11/2018, University of Johannesburg.

Andreoni, A., Chang, H.-J. and Estevez, I. 2019. New Global Rules, Policy Space and Quality of Growth in Africa, in Noman, A. and J. Stiglitz, eds., Quality of Growth in Africa, Columbia University Press.

Badaracco, J. \& Yoffie, D. 1983. Industrial Policy: It Can't Happen Here, Harvard Business Review, Nov./Dec.

Balassa, B. 1988. The Lessons of East Asian Development: An Overview, Economic Development and Cultural Changes, vol. 36, no. 3, Apr. 1988, Supplement.

Balogh, T. 1982. The Irrelevance of Conventional Economics, New York: W.W. Norton.

Becattini, G. 1989. Sectors and/or districts: some remarks on the conceptual foundations of industrial economics, in Goodman, E. and Bamford, J. with Saynor, P. (eds.), Small Firms and Industrial Districts in Italy, London, Routledge.

Best, M. 1990. The New Competition. Institutions of Industrial Restructuring, Cambridge: Polity Press.

Brisco, N. 1907. The Economic Policy of Robert Walpole, Columbia University Press, New York.

Chang, H-J. 1994a. The Political Economy of Industrial Policy, Basingstoke, Macmillan.

Chang, H.J. 1994b State, Institutions and Structural Change, Structural Change and Economic Dynamics, 5(2), 293-313.

Chang, H-J. 1995. Explaining "Flexible Rigidities" in East Asia, in T. Killick (ed.), The Flexible Economy - Causes and Consequences of the Adaptability of National Economies, London, Routledge.

Chang, H-J. 2002. Kicking Away the Ladder - Development Strategy in Historical Perspective, London, Anthem Press.

Chang, H-J. 2007a. Bad Samaritans, London, Random House, and New York, Bloomsbury USA.

Chang, H-J. 2007b. (ed.). Institutional Change and Economic Development, Anthem Press, London.

Chang, H-J. 2011a. 'Industrial Policy: Can We Go Beyond an Unproductive Confrontation?' in J. Lin and B. Pleskovic, (eds.), Annual World Bank Conference on Development Economics 2010, Global: Lessons from East Asia and the Global Financial Crisis, Washington, DC, World Bank.

Chang, H-J. 2011b. Institutions and Economic Development: Theory, Policy, and History, Journal of Institutional Economics, 7, 4.

Chang, H.J. and Rowthorn, B. 1995 eds., Role of the State in Economic Change, Oxford: Oxford University Press. 
Chang, H-J. and Andreoni, A. 2016. Industrial Policy in a Changing World, Cambridge Journal of Economics 40 Years Conference, Cambridge.

Chang, H-J. and Andreoni, A. 2019. Institutions and the process of industrialisation: Towards a theory of social capability development, in Nissanke, M. and J.A. Ocampo, eds., The Palgrave Handbook of Development Economics: Critical Reflections on Globalization and Development, Palgrave.

Chenery, H. 1959. The interdependence of Investment Decision, in Abramovitz M. et al., eds., The Allocation of Economic Resources, Stanford: Stanford University Press.

Cohen, S. 1977. Modern Capitalist Planning: The French Model, 2nd edition, Berkeley, University of California Press

Cohen, S. and DeLong, J.B.. 2016. Concrete Economics, Harvard Business Review Press, Cambridge, MA and London.

Cohen, S. \& Zysman, J. 1987. Manufacturing Matters, New York, Basic Books

Dahmen, E. (1989) Development Blocks in Industrial Economics, reprinted in Carlsoon, B. and R. Henriksson, eds., Development Blocks and Industrial Transformation. The Dahemian Approach to Economic Development, Stockholm: The Industrial Institute for Economic and Social Research 136-149.

David, P.A. 1990. The dynamo and the computer: an historical perspective on the modern productivity paradox, American Economic Review, 80, 355-361.

Dertouzos, M., Lester, R. and Solow, R. Made in America: Regaining the Productive, Cambridge MA, MIT Press.

Dogdson, M., Hughes, A. Foster, J. and Metcalfe, S. 2011. System thinking, market failure, and the development of innovation policy: The case of Australia, Research Policy, 40, 1145-1156.

Dore, R. 1986. Flexible Rigidities: Industrial Policy and Structural Adjustment in the Japanese Economy 1970-80, London, The Athlone Press

Ellman, M. 1979. Socialist Planning, Cambridge, Cambridge University Press.

Erlich, A. 1960. The Soviet Industrialization Debate, 1924-28, Cambridge, Massachusetts, Harvard University Press.

Evans, P. 1995. Embedded Autonomy. States and Industrial Transformation, Princeton University Press, Princeton.

Gerschenkron, A. 1955. Notes on the rate of industrial growth in Italy, 1881-1913, Journal of Economic History, 5(4), 360-375.

Gerschenkron, A. 1962. Economic Backwardness in Historical Perspective, Cambridge, Mass.: Harvard University Press.

Hall, P. 1987. Governing the Economy, Cambridge, Polity Press

Hamilton, A. 1791. Report on the Subject of Manufactures, Philadelphia, December 5.

Hayward, J. 1986. The State and the Market Economy, Brighton, Wheatsheaf Books. 
Hausmann, R. \& Rodrik, D. 2002. Economic Development as Self-discovery, Working Paper no. 8952, National Bureau of Economic Research.

Hausmann, R. \& Rodrik, D. 2006. Doomed to Choose - Industrial Policy as Predicament, mimeo., John F. Kennedy School of Government, Harvard University.

Hidalgo, C. \& Hausmann, R. 2009. The Building Blocks of Economic Complexity, Proceedings of the National Academy of Sciences, vol. 106, no. 26.

Hirschman, A. O. 1958. The Strategy of Economic Development, New Haven, Conn.: Yale University Press.

Hont, I. 2005. Jealousy of Trade: International Competition and the Nation-State in Historical Perspective, Harvard University Press, Cambridge, MA and London.

Johnson, C. 1982. MITI and the Japanese Miracle, Stanford, Stanford University Press

Kaldor, N. 1966. Causes of the Slow Rate of Economic Growth of the United Kingdom, Cambridge, Cambridge University Press.

Kaldor, N. (1985) Economics Without Equilibrium, New York, ME Sharpe Inc.

Kalecki, M. (1976) Essays on Developing Economies, Atlantic Highlands, NJ, Humanities Press.

Katzenstein, P. 1985. Small States in World Markets, Ithaca, Cornell University Press

Klein Woolthuis, R., Lankhuizen, M. and Gilsing, V. (2005), A system failure framework for innovation policy design, Technovation, 25, 609-619.

Kuznets, S. 1973. Modern Economic Growth: findings and reflections, American Economic Review, 63, 247-258.

Lall, S. 1994. The East Asian Economic Miracle: Does the Bell Toll for Industrial Strategy?, World Development, 22, 4.

Lall, S. 2001. Competitiveness, Technology and Skills, Edward Elgar.

Landesmann, M. 1992. Industrial Policy and Social Corporatism, in J.Pekkarinen, M. Pohjola and B. Rowthorn, eds., Social Corporatism, Oxford, Oxford University Press.

Landesmann, M. and Scazzieri, R. 1990. Specification of Structure and Economic Dynamics, in Baranzini M. and R. Scazzieri, eds., The Economic Theory of Structure and Change, Cambridge, Cambridge University Press.

Laranja, M., Uyarra, E. and Flanagan, K. 2008. Policies for science, technology and innovation: Translating rationales into regional policies in a multi-level setting, Research Policy, 37, 823-835.

Lazonick, W. 1990. Competitive Advantage on the Shop Floor, Harvard University Press, Cambridge, MA and London.

Lazonick in this special issue

Lin, J. 2012. New Structural Economics - A Framework for Rethinking Development and Policy, Washington D.C., World Bank. 
Lin, J. \& Chang, H-J. 2009. Should industrial policy in developing countries conform to comparative advantage or defy it? - A debate between Justin Lin and Ha-Joon Chang, Development Policy Review, 2009, 27, 5.

List, F. 1885 [1841]. The National System of Political Economy, trans. Sampson S. Lloyd, London, Longmans, Green.

Magaziner, I. \& Hout, T. 1980. Japanese Industrial Policy, London, Policy Studies Institute.

Malerba, F. 2002. Sectoral system of innovation and production, Research Policy, 31, 247264

Metcalfe, S. 1995. Technology systems and technology policy in an evolutionary framework, Cambridge Journal of Economics, 19, 25-46.

Milberg, W., Winkler, D. 2013. Outsourcing Economics. Global Value Chains in Capitalist Development, Cambridge, Cambridge University Press.

Myrdal, G. 1958. Economic Theory and Underdeveloped Regions, London, Methuen and Company.

Okimoto, D. 1989. Between MITI and the Market: Japanese Industrial Policy for High Technology, Stanford, CA, Stanford University Press.

O'Sullivan, E., Andreoni, A., Lopez-Gomez, C. and Gregory, M. 2013. What is New in the New Industrial Policies?, Oxford Review of Economic Policy, 29, 2, 432-462.

Pasinetti, L. L. 1981. Structural Change and Economic Growth: A Theoretical Essay on the Dynamics of the Wealth of Nations, Cambridge, Cambridge University Press

Pasinetti, L.L. 2012. Growth and Structural Change and The Significance of Structural Economic Dynamics, in Arena, R. and P.L. Porta, eds., Structural Dynamics and Economic Growth, Cambridge, Cambridge University Press.

Piore, M. \& Sabel, C. 1984. The Second Industrial Divide, New York, Basic Books.

Perroux, F. 1955. Note sur la notion de pole de croissance, Cahiers de l'Institut de science économique appliqué, $\mathrm{D}, 8$.

Prebisch, R., 1950. The Economic Development of Latin America and Its Principal Problems. Economic Bulletin for Latin America, 7, 1-12.

Reich, R. 1982. Why the U.S. Needs an Industrial Policy, Harvard Business Review, Jan./Feb.

Reinert, E. 1995. Competitiveness and its predecessors--a 500-year cross-national perspective, Structural Change and Economic Dynamics, 1995, vol. 6, issue 1, 23-42

Richardson, G. B. 1972. The Organisation of Industry, The Economic Journal, 82(327), 883896.

Rodrik, D. 1994. King Kong Meets Godzilla, in A. Fishlow et al., Miracle or Design? Lessons from the East Asian Experience, Washington, D.C., Overseas Development Council.

Rodrik, D. 2004. Industrial Policy for the Twenty-First Century, UNIDO Working paper. 
Rosenberg, N. 1963. Technological Change in the Machine Tool Industry, 1840 - 1910, Journal of Economic History, 23, 4, 414-443.

Rosenberg, N. 1969. The direction of technological change: inducement mechanisms and focusing devices, Economic Development and Cultural Change, 18, 1-24.

Rosenberg, N. 1982. Inside the Black Box: Technology and Economics, Cambridge, Cambridge University Press.

Rosenberg, N. (1994) Exploring the black box: technology, economics, and history, Cambridge, Cambridge University Press.

Roseinstein-Rodan, P. 1957. Notes on the Theory of the "Big Push", MIT Centre for International Studies.

Schön L (2000) Electricity, technological change and productivity in Swedish industry 18901990, European Review of Economic History, 2, 175-194.

Scitovsky, T. 1954. Two Concepts of External Economies, Journal of Political Economy, 62, 143-151.

Serra, A. 1613. Breve trattato delle cause, che possono far abbondare li regni d'oro, e argento, dove non sono miniere, Lazzaro Scoriggio, Napoli.

Smith, A., 1976[1776]. An Inquiry into the Nature and Causes of the Wealth of Nations, General Editors R.H. Campbell and A.S. Skinner, Clarendon Press, Oxford.

Soete, L. 2007. From Industrial to Innovation Policy, Journal of Industrial Competitiveness and Trade, 7, 273-284.

Spaventa, L. 1959. Dualism in Economic Growth, BNL Quarterly Review, December.

Spaventa, L. 1960. Problems of Intermediate Stages of Growth, Economic Weekly, 10771082 .

Stiglitz, J. 1996. Some Lessons from the East Asian Miracle, World Bank Research Observer, 11(2), 151-177.

Stiglitz, J. and Greenwald, B. 2014. Creating a Learning Society, New York, Columbia University Press.

Tassey, G. 2014. Competing in Advanced Manufacturing: The Need for Improved Growth Models and Policies, Journal of Economic Perspectives, 28, 1, 27-48.

Toner, P. 1999. Main Currents in Cumulative Causation Theory, London, McMillan.

Toye, J. 1987. Dilemmas of Development, Blackwell, Oxford.

Trezise, P. 1983. Industrial Policy is not the Major Reason for Japan's Success, The Brookings Review, vol. 1, spring.

UNCTAD 2018. Investment and New Industrial Policies, World Investment Report, UNCTAD, Geneva

Van Der Hoeven, R. 2008. Alice Amdsen Interview by Rolph van Der Hoeven, Development and Change, 39,6, 1091-1099. 
Young, A.A. 1928. Increasing Returns and Economic Progress, The Economic Journal, 38 (December), 527-42.

Wade, R. 1990. Governing the Market, Princeton, Princeton University Press

Wade, R. 2012. Return of industrial policy?, International Review of Applied Economics, 26:2, 223-239.

World Bank 1993. The East Asian Miracle - Economic Growth and Public Policy, New York, Oxford University Press. 